\title{
GROWTH AND BASIC WOOD PROPERTIES OF BLACK-SPRUCE ALONG AN ALTI-LATITUDINAL GRADIENT IN QUEBEC, CANADA
}

Executive summary: Northern stands are expected to produce wood with higher quality, making these areas attractive for the forest industry. This hypothesis was not be accepted by the analysis. Thus, the reduction in growth would not be compensated by increases in basic properties of wood.

\begin{abstract}
Context Canadian forest industry is turning its interest towards the unmanaged areas at higher latitudes, where the forest resource is still poorly understood because of its lack of accessibility. Despite a lower productivity in terms of volume, northern stands are expected to produce wood with higher quality, which may make these areas attractive for production and management.
\end{abstract}

Aims To test hypothesis that trees of high latitudes produce wood of better basic wood properties than trees of lower latitudes.

Methods Growth and wood characteristics were assessed according to cambial age in 25 black spruce (Picea mariana) trees from five sites located along an alti-latitudinal gradient in Quebec.

Results Sites of highest latitudes and altitudes exhibited slower growth rates and lower stem volume. Wood density and mechanical properties were higher in the sites located at the lower latitudes or altitudes. Fiber size had higher values in southern sites, but only at younger ages. Principal component analysis confirmed these results, with the northernmost site being the one where growth, density and mechanical properties were generally lowest.

Conclusion The reduction in growth was not be compensated by increases in the basic properties of wood. More extensive samplings are needed to validate the results at larger scale.

Keywords: boreal forest, cambial age, fibre length, modulus of elasticity, modulus of rupture, wood density. 


\section{INTRODUCTION}

In Canada, management of the boreal forest exhibits a marked latitudinal gradient because of the inaccessibility and remoteness of the northern stands. Forest management practices have historically been focussed in the south, close to the densely inhabited part of the country, where logistical problems and requirements for new infrastructure are minor, and productivity in terms of growth is generally higher. Nowadays, logging activities are gradually moving towards more remote areas at higher latitudes. In Quebec, a northern boundary to the commercial forest has been established between the $51^{\text {st }}$ and $52^{\text {nd }}$ parallels according to criteria of preservation of biodiversity, physical and climatic constraints, forest fire recurrence and productivity (Ministère des Ressources Naturelles 2000). This administrative boundary has excluded a huge part of the northern territory and reduced the possibility of benefitting from the productive potential offered by $25 \%$ of the closed boreal forest in Quebec. The boreal forest is extensively studied within the zone between the $49^{\text {th }}$ and $51^{\text {st }}$ parallels, its major managed area (Lussier et al. 2002). Consequently, the boundary was set despite very scarce knowledge about the dynamics and productivity of the remote and inaccessible northern stands. As long as the growth, in terms of quality and quantity of wood produced, of these high-latitude forests remain unknown, no strategy based on an economically-advantageous management of the remote areas can be evaluated or considered.

In conifers, size and arrangements of the tracheids determine the properties of lumber and pulp (Zobel and van Buijtenen 1989). Similarly, tracheid morphology plays an important role in the physical properties of wood and affects flexibility, plasticity and resistance (Zobel and van Buijtenen 1989). Density is recognized as one of the most important components of mechanical resistance to deformation under applied load, integrating cell size, cell wall thickness and latewood proportion (Lindstrom 1997). It is commonly accepted that rapid growth of trees results in wood with low-density and shorter fibres (see Zobel and van Buijtenen 1989 for a review). However, variable and even occasionally contrasting responses have been found between tree species and sites. Current knowledge suggests that the relationships between growth rate and basic wood properties seem to be related to the species and the environment where trees grow, and are hard to predict without specific preliminary investigations.

Black spruce [Picea mariana (Mill.) BSP] grows in a broad transcontinental band from Alaska to Newfoundland, but only forms extended closed forests in north-eastern North America. Its abundance and properties make this species very popular for the forest industry in Quebec (Viereck and Johnson 1990). Despite this wide geographical distribution, reaching the $58^{\text {th }}$ parallel, the range of the commercial forest is considerably narrower. Beyond $51^{\circ} \mathrm{N}$, black spruce stands remain partially unknown because of their lower commercial interest. On one hand, utilisation of the stands at higher latitudes clearly requires bigger investments, which would hardly be compensated by the expected lower productivity (Rossi et al. 2010). On the other, the growth reductions under harsh climatic conditions may be associated to higher wood density and/or improved basic wood properties. If this hypothesis was confirmed, these high-latitude and slow-growing stands could constitute a key resource contributing to the competitiveness of the Canadian forest industry.

Latitude and altitude affect growth and wood traits. Changes in wood densities were observed with latitude, but data had previously to be adjusted for tree-ring width (Wiemann and Williamson 2002, Høibø and Vestøl 2010, Zhang et al. 2011). Because of their relationship with wood density, also the mechanical resistance of wood was expected to change with latitude (Høibø and Vestøl 2010). Across wide geographical areas, these changes could be species-specific and related to variation in temperature or precipitation, according to the climatic characteristics of the ecosystems. Thus, although in cold climates a reduction in growth at the higher latitudes and altitudes could be reasonably expected, at the moment of writing, no general rule can be proposed about the pattern of variation of basic wood properties. The aim of this paper was to evaluate growth and wood characteristics and properties of trees growing along an alti-latitudinal gradient covering the whole closed black-spruce forest in Quebec, Canada. The sites selected for this study corresponded to a thermal gradient. Under increasing altitude or latitude, thermal constraints were expected to affect the rate of growth as well as xylem cell characteristics. These changes in wood 
anatomy could lead to different properties of the resulting wood. Thus, a hypothesis was tested that the low productivity of trees growing at the higher latitudes is compensated by better basic wood properties, in terms of density, fibre length or mechanical resistance. As growth and wood properties change with age and social status of the tree, in this study the five largest trees per site were selected, which were expected to represent the potentiality of the site. 


\section{MATERIALS AND METHODS}

\subsection{Study area and tree selection}

The investigation was conducted on trees collected from five permanent plots along an alti-latitudinal gradient ranging between the $48^{\text {th }}$ and $53^{\text {rd }}$ parallels in the coniferous boreal forest of Quebec (Canada) (Fig. 1 and Table 1). Simoncouche (abbreviated as SIM) and Bernatchez (BER) were located in the balsam fir [Abies balsamea (L.) Mill.)] - white birch (Betula papyrifera Marsh.) bioclimatic domain, while Mistassibi (MIS) and Camp Daniel (DAN) were located in the black spruce-moss bioclimatic domain. In these sites, forest stands are fairly uniform in size and age and extensively dominated by black spruce. Mirage (MIR) was located in the black spruce-lichen domain, extending at the boundary of the taiga subzone, where stands show lower density and growth. Sites were composed of even-aged, mature, closed and pure black spruce stands. Because of their remote location and the absence of evidence of human impact, all stands were considered to have developed under the influence of natural disturbances only.

The climate of the area is typically boreal, with very cold winters showing absolute minimum temperatures lower than $-45^{\circ} \mathrm{C}$ and short and cool summers. The sites experience an annual temperature comprised between -1.6 and $4.1{ }^{\circ} \mathrm{C}$ and total precipitation of 827-1162 mm (Table 1). May-September mean temperatures range between 11.1 and $14.6{ }^{\circ} \mathrm{C}$. The temperatures change according to latitude and altitude, with the sites located at the higher altitudes being the coldest in winter and the less warm in summer. Higher precipitations are observed at the southern sites (Table 1). More information about climatic conditions of the sample stands is reported in Rossi et al. (in press).

In each site, five dominant trees were selected from among those with the largest diameters at breast height (DBH) (Table 1). Trees with crotch, evident damage due to wood parasites, reduced or partially dead crowns were excluded from the selection. Tree selection was based on a preliminary assessment of the juvenile growth to assure that only trees developed after a stand-replacing disturbance and belonging to the first cohort were selected. This assessment consisted in analysing the growth pattern of tree-ring width measured at the stem base. Long periods with small increments in diameter during the juvenile age indicated that trees had regenerated in the understory and experienced a suppression by dominant individuals and were excluded from the analysis.

\subsection{Stem growth}

Discs were collected along the stem at sampling heights of $0,0.5,1,1.3$ and $2 \mathrm{~m}$ from the root collar. Above $2 \mathrm{~m}$, discs were collected at intervals of $1 \mathrm{~m}$ for the remaining length of the stem. Discs were air-dried and sanded with progressively finer grade sandpaper. Tree-ring widths and latewood proportion were measured to the nearest 0.01 mm using a WinDENDRO measuring system (Regent Instruments Inc., Canada) along two or four paths for discs collected at heights higher or lower than $2 \mathrm{~m}$, respectively (Tremblay et al. 2011). The tree-ring width series were corrected by cross-dating performed both visually and using the COFECHA computer program (Holmes 1983) and averaged for each disc and tree ring. Tree height $\left(H_{i j}\right)$ at age $t_{i j}$ was estimated for the 5 dominant trees using the Carmean (1972) method. Stem volume was calculated by adding the volume of all tree sections envisaged as truncated cones (Tremblay et al., 2011).

\subsection{Wood anatomy}

Small wood samples were collected on one tree ring out of three and along two paths per tree at the disc sampled at $1 \mathrm{~m}$ from the root collar. The samples were dehydrated by successive immersions in ethanol and D-limonene, embedded in paraffin, and transverse sections of $7 \mu \mathrm{m}$ thickness were cut with a rotary microtome (Rossi et al., 
2006a). The sections were stained with aqueous $1 \%$ safranin and fixed on slides with histological mounting medium. A camera mounted on an optical microscope was used to record the digital images and measure the xylem features with an image analysis system specifically designed for wood cells (WinCELL, Regent Instruments Inc., Canada). Cell features (lumen area, radial diameter and wall thickness) were measured along the tree ring at a magnification of 400x. At that magnification, measurements included a band of 12-18 rows of cells, for a total of about $250 \mu \mathrm{m}$ in thickness.

The hydraulic diameter (HD) of xylem conduits was calculated by selecting all the $N$ cells with a diameter of more than half the diameter of the largest one (Mencuccini et al. 1997) according to the following equation:

$$
H D=\frac{\sum_{n=1}^{N} d_{n}^{5}}{\sum_{n=1}^{N} d_{n}^{4}}
$$

where $d_{n}$ is the diameter of the $n$ cell which weights the hydraulic diameters of single cells according to hydraulic conductance (Sperry et al., 1994). Unlike cell diameter, which derives from an average of all tracheids, hydraulic diameter is calculated on the largest cells of the tree ring, and allow to supply a precise information about the conductivity of the tissues.

\subsection{Fibre size}

Other samples collected close to those used for wood anatomy were macerated in a solution of equal volume of glacial acetic acid and hydrogen peroxide and heated at $60^{\circ} \mathrm{C}$ for $1-2$ days (Franklin 1945). The resulting suspension was hydrated with distilled water and shaken for 30 seconds for a homogenous separation of the fibres. In each sample, length and diameter of 5000 fibres were measured using a Fiber Tester (Lorentzen \& Wettre, Kista, Sweden).

\subsection{Wood density}

Profiles of variation in wood density with cambial age were measured at DBH on samples $1.7 \pm 0.02 \mathrm{~mm}$ thick kept in a conditioning room at $20^{\circ} \mathrm{C}$ and $65 \%$ of relative humidity until they reached a stable moisture content of ca. $12 \%$. Measurements were performed by scanning the samples from bark to pith with an X-ray densitometer QTRS01X Tree Ring Scanner (Quintek Measurement System, Knoxville, TN) at intervals of $4 \mu \mathrm{m}$, and the resulting data were averaged per tree ring. The demarcation zone among tree rings was both automatically set up by the device and checked manually for every tree ring scanned. The average wood density of the tree ring was used in this study.

\subsection{Mechanical properties}

Bending tests were performed according to ASTM D143-09 standard for small specimens on samples $(2.5 \mathrm{~cm} \times$ $2.5 \mathrm{~cm} \times 41 \mathrm{~cm}$ ) collected from the stem between 0.5 and $1 \mathrm{~m}$ from the collar. Samples were collected at various distances from the centre of the stem and the cambial age of the tree rings was recorded. Samples were kept in a conditioning room at $20^{\circ} \mathrm{C}$ and $65 \%$ of relative humidity until they reached a stable moisture content of ca. $12 \%$. The specimens were laid pith side up with growth rings in the horizontal position with a span of $360 \mathrm{~mm}$ among supports $(L)$. Modulus of elasticity (MOE) and rupture (MOR) were assessed on samples of $b$ width and $d$ thickness using an MTS-Alliance RT/100 machine (TestResources Inc., Shakopee, MN) according to 
and

$$
M O E=\frac{P_{1} L^{3}}{4 b d^{3} y}
$$

$$
M O R=\frac{3 P_{2} L}{2 b d^{2}}
$$

where $y$ represents the deflection and $P_{1}$ and $P_{2}$ the maximum loads of elastic domain and rupture, respectively (Wangaard, 1950). In this study, the coefficients $b$ and $d$ had the same value of $2.5 \mathrm{~cm}$.

\subsection{Statistical analyses}

For each site, the patterns of variation of the measured traits $(y)$ with cambial age $(x)$ were fitted with Gompertz functions (for the variables DBH, tree height and stem volume) or Generalised Additive Models (GAM) in SAS (SAS Institute Inc., Cary, NC) using the variable site as fixed effect. The statistical procedures regressed the residuals on the model partial derivatives with respect to the parameters of the Gompertz function until the estimates converged. Several possible starting values were specified for each parameter, so that the procedure evaluated each combination of initial values using the interactions. Goodness-of-fit of the non-linear regressions regression involved the proportion of variation accounted for $\left(\mathrm{R}^{2}\right)$ and the distribution of residuals. GAMs are semi-parametric extensions of generalized linear models that are able to deal with highly non-linear and nonmonotonic relationships and to accurately represent patterns of biological systems (Cuny et al. 2013).

The study produced a multivariate dataset that was interpreted by using principal component analysis (PCA). The patterns of variation of the measured traits estimated in each site at the cambial ages of 20, 40, 60 and 80 years were selected and used for performing PCA based on the method of alternating least squares (PRINQUAL procedure in SAS). These ages were selected because data were available for all sites. A Kruskal secondary least squares monotonic transformation was applied to all variables, with the restriction that ties were preserved. Results were presented by a PCA biplot per each cambial age analysed that showed the transformed variables (e.g. the measured traits) projected onto the two-dimensional plane of the analysis described by the two principal components. PCA allowed to reduce the dimensionality of the multivariate dataset by minimizing multicollinearity and associating the correlated variables in two principal axes. This approach improved data exploration and simplified the interpretation of the results. 


\section{RESULTS}

\subsection{Curve fitting}

In general, the regressions for DBH, stem height and tree volume explained a large proportion of variation with $\mathrm{R}^{2}$ ranging between 0.82 and 0.98 (Table 2). All resulting F-values were significant at $p<0.0001$. The residuals of the studied traits were distributed homogeneously around zero, with distributions showing the presence of some outliers for lumen area, cell and hydraulic diameter, cell wall thickness, fibre width and MOE (Supplementary Material Fig. S1). Distributions were sufficiently symmetric and regular for confirming a satisfactory fitting of both Gompertz functions and GAMs. However, the beginning of the Gompertz function was distant from the origin and overestimated the observations of DBH and tree height for the first 5-7 years. Data were markedly heteroscedastic, mainly for DBH and stem volume, with the highest variability among cambial ages observed after 30 years. Overestimations were also detected at ages $<20$ years for hydraulic diameter (Supplementary Material Fig. S1).

\subsection{Measured traits vs. cambial age}

The growth in DBH, height and volume followed a sigmoid pattern (Fig. 3). A gradual initial increase was followed by a more rapid growth rate, which was attained at more mature ages in trees of BER, DAN and MIR. After the sharp increase, growth rate of height and DBH slowed down reaching an asymptote that was substantially similar among sites for DBH, but not for height. Volume increased later and more slowly than height and DBH, remaining at values below $20 \mathrm{dm}^{3}$ for the first 20-40 years, according to the site (Fig. 3). Except for SIM, no asymptote for volume was reached by the sampled trees at 120 years.

In all sites, lumen area and cell diameter on average increased with cambial age at younger ages, after which several patterns were observed (Fig. 3). A plateau around values of $350 \mu \mathrm{m}^{2}$ and $25-26 \mu \mathrm{m}$ were observed in DAN and BER after 50 years for lumen area and cell diameter, respectively. Between 50 and 60 years, SIM and MIS showed marked reductions in cell sizes. In MIR, cell size grew monotonically but showed the lowest values between sites until 40 years, attaining the largest values after 55-65 years. For all sites, hydraulic diameter increased in the same way, but with more stable values at older ages, than cell diameter. In MIR hydraulic diameter exceeded those measured in the other sites at 80 years.

Cell wall thickness increased monotonically with age but according to different growth rates between sites (Fig. 3). After 30 years, SIM and MIS showed cells with thicker walls. At 80 years, cell walls in SIM were approximately 1.5 times thicker than those in MIR. Wood density followed a similar pattern than cell wall thickness. DAN, BER and MIR exhibited a wood density of c.a. $520 \mathrm{~kg} \mathrm{~m}^{-3}$ at 80 years, $11 \%$ less than that estimated in SIM and MIS at the same age.

Fibre length and diameter exhibited an initial rapid increase that slowed down or reached a plateau after 40-50 years of age (Fig. 3). For both traits, SIM and MIS had the highest values at younger ages, but SIM showed an early culmination with lower values than the others sites after 45 and 65 years for fibre diameter and length, respectively. Thus, fibres of the 60 -years-old trees in SIM were $2.3 \times 10^{3} \mu \mathrm{m}$ in length and $30 \mu \mathrm{m}$ thick, values similar to those observed in trees of MIR at the same age.

MOE and MOR increased linearly with age until 40-60 years (Fig. 3). At 20 years, SIM and BER showed the highest values, on average $7 \times 10^{3} \mathrm{~N} \mathrm{~mm}^{-2}$ and $80 \mathrm{~N} \mathrm{~mm}^{-2}$, for MOE and MOR, respectively. DAN and MIR showed the lowest values of MOE and MOR, except for MOE in DAN after 60 years, which revealed an permanently increasing trend even at the older ages. 
The proportion of latewood in the tree ring increased with cambial age, mainly between 20 and 40 years (Fig. 4). After 40 years, latewood proportion remained approximately constant, or increased more slowly. SIM and MIS showed the highest amount of latewood between 40 and 80 years (29-35\%), while the lowest proportions were observed in DAN and BER (24-26\%).

\subsection{Measured traits vs. distance from the pith}

When plotted in respect to the distance from the pith, some measured traits showed different patterns than those observed with cambial age (Fig. QQQ). Lumen area, cell diameter and hydraulic diameter increased with the distance from the pith and attained a plateau at approximately $6 \mathrm{~cm}$. No plateau was observed in MIR. At small DBH, SIM had larger cell sizes than MIR, while an opposite situation was observed at bigger DBH. Cell wall thickness and wood density exhibited the same pattern, with a slow increase until $8 \mathrm{~cm}$ from the pith, after which the growth rate changed abruptly (Fig. QQQ). MIR and SIM had the thinnest cell walls and the lowest wood densities, while MIS showed the highest values of cell walls and wood density.

Fibre length increased with the distance from the pith, but with different growth rates and patterns between sites (Fig. QQQ). Fibre diameter had the same pattern than fibre length and was not shown. At distances from the pith $>4 \mathrm{~cm}$, SIM and MIR had fibers with the shortest lengths. Patterns and relative distances between sites of MOE and MOR were similar to those observed with cambial age, and increased with the distance from the pith (compare Fig. 3 with Fig. QQQ). Thus MIR exhibited the lowest values of resistance to deformation and rupture, while the highest MOE and MOR were generally observed in SIM and BER.

\subsection{Principal component analysis}

The transformed variables of the measured traits as well as the five sites were projected onto two-dimensional planes generated by the first two canonical axes (Fig. 5). Sites located along the same direction or in the opposite direction to a measured trait showed high or low values of that trait, respectively. Canonical axes 1 represented between 55.9 and $78.0 \%$ of the variability, while the variance accounted for by canonical axes 2 ranged between 21.9 and $44.0 \%$. At all ages, canonical axis 1 represented mainly tree growth, thus, the sites located on the left tended to have smaller trees than those on the right, except at 60 years, where smaller trees were located on the right. The relationship between canonical axis 2 and the measured traits was more complex and changed with age (Fig. 5).

Similar directions with respect to the origin revealed high correlations between the variables of the measured traits. Such situations occurred at all ages for wood density and cell wall thickness at 20, 40 and 60 years, and for MOE and fibre length at 20,60 and 80 years. Mechanical properties showed low or no correlation with wood density, and frequently occurred along perpendicular directions.

SIM and MIR, the two extreme sites of the gradient, were always distinctly separated (Fig. 5). MIR coincided with BER and DAN at 20 and 60 years. SIM tended to be located along similar directions than tree height, DBH and stem volume at all ages, and had high MOE and MOR at 20 and 40 years. At 60 and 80 years, MOE and MOR were not correlated or negatively correlated with SIM, but these results should be considered with caution because data of MOE and MOR were not available at these ages and the matrix was incomplete for these traits for SIM (Fig. 3). SIM showed the higher wood density at 60 and 80 years. MIR was always located in the opposite direction to tree height, DBH and stem volume, confirming its low growth. Moreover, MIR was generally the site with a low density and mechanical properties, as revealed by its locations on the two-dimensional planes. At 80 years, MIR showed the larger cell sizes in terms of cell length, lumen area and hydraulic diameter. DAN and BER were on the same direction or even adjacent, indicating similar values of the measured traits. They were located 
closer to the origin than the other sites, which indicated that all correlations with the measured traits were mediocre, except at 20 years, when DAN showed high wood density and BER had thinner cell walls. 


\section{DISCUSSION}

In this paper, growth and wood characteristics were measured and compared between sites at different altitudes and latitudes covering the whole closed black-spruce forest of Quebec, Canada. The study considered each measured variable according to the cambial age. This provided detailed information about the temporal dynamics of change of the wood traits over the entire lifespan of a tree and allowed comparisons to be appropriately performed according to the tree age when wood was produced. As expected, sites at highest latitudes or altitudes exhibited reduced growth rates, which resulted in lower stem volume produced at a given cambial age. However, wood density and mechanical properties were higher in the sites located at the lower latitudes or altitudes. Fiber size had higher values in southern sites, but only for ages lower than 40 years. In particular, the northernmost site had low wood density and the lowest mechanical properties throughout the range of cambial age analysed. Consequently, the initial hypothesis that the slow-growing trees at high latitudes could produce wood of better basic wood properties could not be accepted.

Wood density and growth rate have been repetitively compared. Zobel and van Buijtenen (1989) reported that wood with low density was most frequently observed to be produced by fast-growing trees. In conifers, especially in spruce and fir, narrower tree rings were expected to correspond to higher proportions of latewood cells. This assumption was not confirmed by our findings, because higher latewood proportions were recorded in trees producing wider tree rings. Latewood exhibits a higher density than earlywood, and plays a crucial role in defining the mechanical properties of wood (Leban et al. 1992; Butterfield 2003). However, previous investigations were most frequently performed on young individuals, of less than 40 years, when the proportion of juvenile wood within the tree is substantial (Cregg et al. 1988; Mäkinen et al. 2002; Lenz et al. 2012). Moreover, at this age, the growth rates in height and volume are still elevated in our trees, and they can hardly be considered mature for logging even on the southern sites of the species distribution. Actually, there is increasing evidence that the growth rate has less influence on the mechanical strength than the quality of the site where the trees live (Fernandez-Golfin Seco and Diez Barra 1996; Fernandez-Golfin Seco et al. 2004; Oliva et al. 2006).

Anatomical, physical and chemical properties of wood change with cambial age (Panshin and Zeeuw 1980; Saranpää 2003; Rossi et al. 2012b), as once again confirmed in this study (Fig. 3). As a consequence, the age at which the wood has been produced should necessarily be included, or carefully considered, in all comparisons. However, Butterfield (2003) observed that this expedient has sometimes been ignored, and thus biologicallyincorrect results obtained and interpreted. This was confirmed by the analysis presented in this study, where the measured traits were plotted in respect to cambial age or the distance from the pith (Figs. 3 and QQQ). According to the method of analysis (cambial age or distance from the pith), the measured traits sometimes exhibited different patterns of variation and relative distances between sites, which could lead to different interpretations.

Consequently, the method of analysis is crucial and should be adopted or carefully considered in the interpretation of the results.

The North-American boreal forest is erroneously associated to even-aged ecosystems. This is not the case for all species. Because of the effective survival strategy of black spruce growing in the understory, the formation of multi-cohort structures with uneven-aged age distributions is less infrequent than previously thought (Fricker et al. 2006; Rossi et al. 2013). At maturity, trees of uneven-aged stands show lower growth in height, diameter and volume following the initial suppression by and competition with the dominant layer (Rossi et al. 2009). Consequently, the estimated growth rates could provide imprecise information about effective or potential tree performances where the history of the individuals is not taken into account. The analyses performed in this study were restricted to the trees developed from seeds germinated after a stand-replacing disturbance and belonging to the first cohort. The investigations performed on specimens belonging to the first cohort that developed after stand initiation ensured that the trees experienced similar competition in the different sites and no suppressing periods occurred during their juvenile stages. 
Like the growth, wood properties change with cambial age and follow distinct patterns. In the initial stage, a tree produces juvenile wood, characterized by short fibres with small size and thin cell walls, low density and marginal mechanical properties (Yang and Hazenberg 1994). In black spruce, the transition between juvenile and mature wood is expected to occur at between 11 and 21 years (Yang and Hazenberg 1994; Alteyrac et al. 2006). During the first years of life, the xylem cells serve more for the transport of water and nutrients than for supporting the aboveground organs of the tree (Schneider et al. 2008). Our dataset confirmed this trend because values of most anatomical and mechanical properties were low when measured close to the pith, and then increased.

Trees of the southern sites reached the highest values of basic wood properties, in terms of fibre length or mechanical properties, at younger ages than those of northern sites. These characteristics were associated with cell wall thickness, latewood proportion, and wood density, the most important physical properties of wood (Desch and Dinwoodie 1996; Bowyer et al. 2003). Timings and length of the growing season influence the amount of wood production, and the anatomical features of xylem. Cambial resumption in spring and the ending of xylem differentiation in early autumn change according to latitude and altitude, delimiting a growing season gradually shortening northwards with the changes in temperature and soil fertility (Moser et al. 2010; Rossi et al. 2012a). Cell wall thickness is related in equal part to rate and duration of the deposition of cellulose microfibrils (Cuny 2013), both being dependent on temperature, which decreases with latitude and altitude. Thus, an earlier onset of the growing season provides a longer period for cell production, and more time for cell maturation, including cell wall thickening and lignification (Gingl et al. 2000, 2001; Rossi et al. 2012a). Accordingly, the shorter growing season at the highest latitudes reduces the period of carbon assimilation by trees and the time allowed for cell wall thickening.

The hydraulic diameter, the measure of the largest cells of each tree ring, was calculated to verify the variation in conductivity of the tissue. Unlike cell diameter that derives from an average of all tracheids, hydraulic diameter is not affected by the small cells and latewood proportion, which play only a marginal role in xylem conductivity. Xylem conduits are not cylindrical, but taper from the stem collar towards the tree top, decreasing their diameter distally (Anfodillo et al. 2006). Also, tapering of xylem conduits seems to be strictly dependent on distance from the tree top, so taller trees exhibit wider xylem conduits at their base (Anfodillo et al. 2006) and explains the reduction in cell dimension observed with latitude (St-Germain and Krause 2008). These hypotheses were confirmed by our observations that the greatest increases in hydraulic diameter occurred during the period of faster height growth. However, in the studied trees, hydraulic diameter culminated early, at cambial ages of between 20 and 50 years, according to the site, well before the culmination in height growth (60-80 years).

The investigation presented in this paper focussed on five sites covering the whole closed black-spruce forest. Despite the limited number of sites sampled, the analyses provided detailed information on the temporal dynamics of changes in wood traits over the entire lifespan of a tree, allowing the comparisons to be precisely performed according to cambial age. Data from this preliminary analysis suggested that the reduction in growth in terms of volume would not be compensated by increases in the basic properties of wood. However, we are aware that our results require additional investigations to be tested or validated with extensive samplings involving more trees and sites, mainly performed in the remote and inaccessible parts of the boreal forest.

\subsection{Conclusions}

The recent global financial crisis and the related low demand for forest products, mainly from the US, has generated several difficulties for the Canadian forest industry. The combination of structural shifts such as the collapse in demand for newsprint and the proliferation of low-cost competitors is requiring the development of specific and diversified products based on the awareness that innovation and competitiveness have to be based on value-added wood products and improved wood quality. Despite the reduced productivity in terms of volume of the northern stands, potential increases in basic wood properties may make the remote areas of the boreal forest 
attractive for the forest industry. In this paper, growth and wood characteristics were compared between sites at different altitudes and latitudes to test if slow-growing trees can be associated with higher wood density and/or improved basic wood properties. As expected, sites of higher latitude and altitude exhibited a slower growth rate. However, wood density, and mechanical properties had lower values, or were reached later, in the northern sites, where growth rates were less vigorous. Consequently, the initial hypothesis that the slow-growing trees of high latitudes could produce wood of better basic properties could not be accepted. Results of this study, performed with a high resolution but on a small sample size, did not provide evidences that the slow-growing trees of higher latitudes could have better basic properties than the trees of southern sites. The eventual future management of the northern boreal forest will have to take into account the effective productivity, in terms of quality and quantity of wood produced, of these regions. 


\section{ACKNOWLEDGEMENTS}

The authors thank J. Boulouf-Lugo, F. Espìn, J.-G. Girard, C. Soucy for technical support, and A. Garside for checking the English text.

\section{FUNDING}

This work was funded by Consortium de Recherche sur la Forêt Boréale Commerciale, Ministère des Ressources naturelles du Québec, and Fonds de Recherche sur la Nature et les Technologies du Québec. 


\section{REFERENCES}

Alteyrac J, Cloutier A, Ung C-H, Zhang SY (2006) Mechanical properties in relation to selected wood characteristics of black spruce. Wood Sci Technol 38:229-237

Anfodillo T, Carraro V, Carrer M, Fior C, Rossi S (2006) Converging tapering of xylem conduits in different woody species. New Phytol 169:279-290

Bowyer J, Shmulsky R, Haygreen JG (2003) Forest products and wood science: an introduction. Iowa State Press, Ames

Butterfield BG (2003) Wood anatomy in relation to wood quality. In: Barnett JR, Jeronimidis G (eds) Wood quality and its biological basis. Blackwell, Oxford, pp 30-52

Carmean WH (1972) Site index curves for upland oaks in the Central States. For Sci 18:109-120

Cregg BM, Dougherty PM, Hennessey TC (1988) Growth and wood quality of young loblolly pine trees in relation to stand density and climatic factors. Can J For Res 18:851-858

Cuny H (2013) Dynamique intra-annuelle de la formation du bois de trois espèce de conifères (sapin pectiné, épicéa commun, pin sylvestre) dans les Vosges. PhD thesis, Université de Lorraine, Nancy

Desch HE, Dinwoodie JM (1996) Timber: its structure, properties, conversion and use. Macmillan Press Ltd, London

Fernandez-Golfin Seco JI, Diez Barra MR (1996) Growth rate as a predictor of density and mechanical quality of sawn timber from fast growing species. Holz als Roh- und Werkstoff 54:171-174

Fernandez-Golfin Seco JI, Diez Barra MR, Hermoso Prieto E, Conde Garcia M (2004) Mechanical characterization of timber from Spanish provenances of laricio pine according to European standards. Wood Sci Technol 38:2534

Franklin GL (1945) Preparing thin section of synthetic resin and wood-resin composites, and a new maceration method for wood. Nature 155:51

Fricker JM, Chen HYH, Wang JR (2006) Stand age structural dynamics of North American boreal forests and implications for forest management. International Forestry Review 8:395-405

Gindl W, Grabner M, Wimmer R (2000) The influence of temperature on latewood lignin content in treeline Norway spruce compared with maximum density and ring width. Trees 14:409-414

Gindl W, Grabner M, Wimmer R (2001) Effects of altitude on tracheid differentiation and lignification of Norway spruce. Can J Bot 79:815-821

Høibø O, Vestøl GI (2010) Modelling the variation in modulus of elasticity and modulus of rupture of Scots pine round timber. Can J For Res 40:668-678

Holmes RL (1983) Computer-assisted quality control in tree-ring dating measurement. Tree-Ring Bulletin 43:6978

Leban JM, Houllier F, Goy B, Colin F (1992) La qualité du bois d'épicéa commun en liaison avec les conditions de croissance. Forêt Entreprise 80:11-27

Lenz P, Bernier-Cardou M, MacKay J, Beaulieu J (2012) Can wood properties be predicted from the morphological traits of a tree? A canonical correlation study of plantation-grown white spruce. Can J For Res 42:1518-1529

Lindstrom H (1997) Fiber length, tracheid diameter, and latewood percentage in Norway spruce: development from pith outwards. Wood Fibre Sci 29:21-34

Lussier J-M, Morin H, Gagnon R (2002) Mortality in black spruce stands of fire or clear-cut origin. Can J For Res 
Mäkinen H, Saranpää P, Linder S (2002) Wood-density variation of Norway spruce in relation to nutrient optimisation and fibre dimensions. Can J For Res 32:185-194

Mencuccini M, Grace J, Fioravanti M (1997) Biomechanical and hydraulic determinants of the tree structure in Scots pine: anatomical characteristics. Tree Physiol 17:105-113

Ministère des Ressources Naturelles (2000) La limite nordique des forêts attribuables. Rapport final du comité. Gouvernement du Québec,

Moser L, Fonti P, Buentgen U, Franzen J, Esper J, Luterbacher J, Frank D (2010) Timing and duration of European larch growing season along altitudinal gradients in the Swiss Alps. Tree Physiol 30:225-233

Oliva AG, Merino VB, Seco JIF-G, García MC, Prieto EH (2006) Effect of growth conditions on wood density of Spanish Pinus nigra. Wood Sci Technol 40:190-204

Panshin AJ, De Zeeuw C (1980 ) Textbook of wood technology. McGraw-Hill, New York

Ressources Naturelles Canada (2012) The state of Canada's forests. Canadian Forest Service, Ottawa

Rossi D, Rossi S, Morin H, Bettero A (2012b) Within-tree variations in the surface free energy of wood assessed by contact angle analysis. Wood Sci Technol 46:287-298

Rossi S, Anfodillo T, Menardi R (2006a) Trephor: a new tool for sampling microcores from tree stems. IAWA J 27:89-97

Rossi S, Girard M-J, Morin H Lengthening of the duration of xylogenesis engenders disproportionate increases in xylem production. Global Change Biol in press

Rossi S, Morin H, Deslauriers A (2012a) Causes and correlations in cambium phenology: towards an integrated framework of xylogenesis. J Exp Bot 63:2117-2126

Rossi S, Morin H, Gionest F, Laprise D (2013) Spatially explicit structure of natural stands dominated by black spruce. Silva Fenn in press

Rossi S, Morin H, Tremblay M-J (2010) Growth and productivity of black spruce (Picea mariana) belonging to the first cohort in stands within and north of the commercial forest in Quebec, Canada. Ann For Sci 67:807

Rossi S, Tremblay M-J, Morin H, Savard G (2009) Growth and productivity of black spruce in even- and unevenaged stands at the limit of the closed boreal forest. For Ecol Manage 258:2153-2161

Saranpää P (2003) Wood density and growth. In: Barnett JR, Jeronimidis G (eds) Wood quality and its biological basis. Blackwell, Oxford, pp 30-52

Schneider R, Zhang SY, Swift DE, Bégin J, Lussier J-M (2008) Predicting selected wood properties of jack pine following commercial thinning. Can J For Res 38:2030-2043

Sperry JS, Nichols KL, Sullivan JE, Eastlack M (1994) Xylem embolism in ring porous, diffuse porous and coniferous trees of northern Utah and interior Alaska. Ecology 75:1736-1752

St-Germain J-L, Krause C (2008) Latitudinal variation in tree-ring and wood cell characteristics of Picea mariana across the continuous boreal forest in Quebec. Can J For Res 38:1397-1405

Tremblay M-J, Rossi S, Morin H (2011) Growth dynamics of black spruce in stands located between the 51st and 52nd parallels in the boreal forest of Quebec, Canada. Can J For Res 41:1769-1778

Viereck LA, Johnson WF (1990) Picea mariana (Mill.) B.S.P., black spruce. In: Burns RM, Honkala BH (eds) Silvics of North America, vol 1: conifers. U.S. Department of Agriculture, Forest Service, Washington, D.C., p 675

Wangaard FF (1950) The mechanical properties of wood. John Wiley \& Sons, New York 
Wiemann MC, Williamson GB (2002) Geographic variation in wood specific gravity: effects of latitude, temperature, and precipitation. Wood Fiber Sci 34:96-102

Yang KC, Hazenberg G (1994) Impact of spacing on tracheid length, relative density, and growth rate of juvenile wood and mature wood in Picea mariana. Can J For Res 24:996-1007

Zhang S-B, Slik JWF, Zhang J-L, Cao K-F (2011) Spatial patterns of wood traits in China are controlled by phylogeny and the environment. Global Ecol Biogeogr 20:241-250

Zobel BJ, van Buijtenen JP (1989) Wood variation - its causes and control. Springer-Verlag, Berlin Heidelberg 


\section{CAPTION LIST}

Table 1 Location, characteristics of the sampled trees, and weather of the five black spruce stands located in the boreal forest of Quebec, Canada, listed at increasing latitude. Values are reported as mean \pm standard deviation

Table 2 Coefficients of the Gompertz functions fitting the growth traits of black spruce trees growing in stands located at different latitudes in the boreal forest of Quebec, Canada. F-values are significant at $\mathrm{p}<0.0001$

Fig. 1 Location of the five study sites in Quebec, Canada

Fig. 3 Pattern of variation of the measured traits with cambial age of black spruce trees growing in stands located at different latitudes in the boreal forest of Quebec, Canada. Data represent values predicted by Gompertz functions and GAMs

Fig. 4 Percentage of latewood at four cambial ages measured in trees of five black spruce stands located at different latitudes in the boreal forest of Quebec, Canada

Fig. QQQ Pattern of variation of the measured traits plotted according to the distance from the pith of black spruce trees growing in stands located at different latitudes in the boreal forest of Quebec, Canada. Data represent the values predicted by GAMs

Fig. 5 Principal component analysis of the measured traits estimated for the five black spruce stands at different cambial ages. DBH and HD indicate diameter at breast height and hydraulic diameter, respectively. Note that some traits were slightly repositioned to improve the readability of the figure 
TABLE 1

\begin{tabular}{|c|c|c|c|c|c|c|c|c|c|}
\hline Site & Latitude & Longitude & $\begin{array}{l}\text { Altitude } \\
\text { (m a.s.1.) }\end{array}$ & $\mathrm{H}(\mathrm{m})$ & $\mathrm{DBH}(\mathrm{cm})$ & Age (years) & $\begin{array}{l}\text { Annual } \\
\text { temperature } \\
\left({ }^{\circ} \mathrm{C}\right)\end{array}$ & $\begin{array}{l}\text { May-September } \\
\text { temperature } \\
\left({ }^{\circ} \mathrm{C}\right)\end{array}$ & $\begin{array}{c}\text { Annual } \\
\text { precipitation } \\
(\mathrm{mm})\end{array}$ \\
\hline SIM & $48^{\circ} 13^{\prime} \mathrm{N}$ & $71^{\circ} 15^{\prime} \mathrm{W}$ & 338 & $17.22 \pm 0.75$ & $20.92 \pm 1.42$ & $80.60 \pm 1.52$ & 4.1 & 14.6 & 1162 \\
\hline BER & $48^{\circ} 51^{\prime} \mathrm{N}$ & $70^{\circ} 20^{\prime} \mathrm{W}$ & 611 & $16.83 \pm 0.82$ & $20.38 \pm 1.82$ & $133.40 \pm 2.72$ & 1.8 & 12.6 & 1109 \\
\hline MIS & $49^{\circ} 43^{\prime} \mathrm{N}$ & $71^{\circ} 56^{\prime} \mathrm{W}$ & 342 & $18.16 \pm 0.79$ & $20.28 \pm 1.58$ & $113.00 \pm 4.00$ & 2.0 & 13.6 & 1009 \\
\hline DAN & $50^{\circ} 41^{\prime} \mathrm{N}$ & $72^{\circ} 11^{\prime} \mathrm{W}$ & 487 & $18.32 \pm 1.27$ & $22.04 \pm 1.69$ & $134.20 \pm 2.56$ & 0.0 & 12.1 & 1006 \\
\hline MIR & $53^{\circ} 47^{\prime} \mathrm{N}$ & $72^{\circ} 52^{\prime} \mathrm{W}$ & 441 & $12.60 \pm 0.70$ & $20.46 \pm 1.10$ & $110.60 \pm 4.32$ & -1.6 & 11.1 & 827 \\
\hline
\end{tabular}


TABLE 2

\begin{tabular}{|c|c|c|c|c|c|c|}
\hline \multirow[b]{2}{*}{ Trait } & \multirow[b]{2}{*}{ Site } & \multicolumn{3}{|c|}{ Coefficients } & \multirow[b]{2}{*}{$\mathrm{F}$} & \multirow[b]{2}{*}{$\mathrm{R}^{2}$} \\
\hline & & $a$ & $b\left(10^{-6}\right)$ & $c$ & & \\
\hline \multirow[t]{5}{*}{$\mathrm{DBH}(\mathrm{cm})$} & SIM & 19.26 & 7.69 & 16.99 & $13.7710^{3}$ & 0.95 \\
\hline & BER & 20.00 & 2.59 & 36.41 & $13.1810^{3}$ & 0.91 \\
\hline & MIS & 20.05 & 3.61 & 28.55 & $98.4910^{2}$ & 0.91 \\
\hline & DAN & 21.06 & 2.82 & 29.29 & $72.3610^{2}$ & 0.83 \\
\hline & MIR & 19.19 & 4.42 & 28.20 & $17.3710^{3}$ & 0.95 \\
\hline \multirow[t]{5}{*}{ Stem height $(\mathrm{m})$} & SIM & 17.57 & 5.25 & 25.98 & $18.4610^{3}$ & 0.97 \\
\hline & BER & 17.67 & 2.68 & 42.80 & $25.2810^{3}$ & 0.96 \\
\hline & MIS & 18.22 & 3.72 & 36.29 & $43.3510^{3}$ & 0.98 \\
\hline & DAN & 20.62 & 2.28 & 46.40 & $18.9710^{3}$ & 0.94 \\
\hline & MIR & 12.68 & 3.97 & 40.15 & $24.5110^{3}$ & 0.97 \\
\hline \multirow[t]{5}{*}{ Tree volume $\left(\mathrm{dm}^{3}\right)$} & SIM & $22.5610^{1}$ & 5.21 & 41.81 & $32.7410^{2}$ & 0.90 \\
\hline & BER & $28.4510^{1}$ & 2.22 & 91.36 & $24.2410^{2}$ & 0.83 \\
\hline & MIS & $29.6110^{1}$ & 2.68 & 72.36 & $21.2310^{2}$ & 0.82 \\
\hline & DAN & $41.0110^{1}$ & 1.87 & 94.67 & $38.2710^{2}$ & 0.87 \\
\hline & MIR & $16.7510^{1}$ & 3.26 & 71.63 & $81.0610^{2}$ & 0.95 \\
\hline
\end{tabular}


FIGURE 1

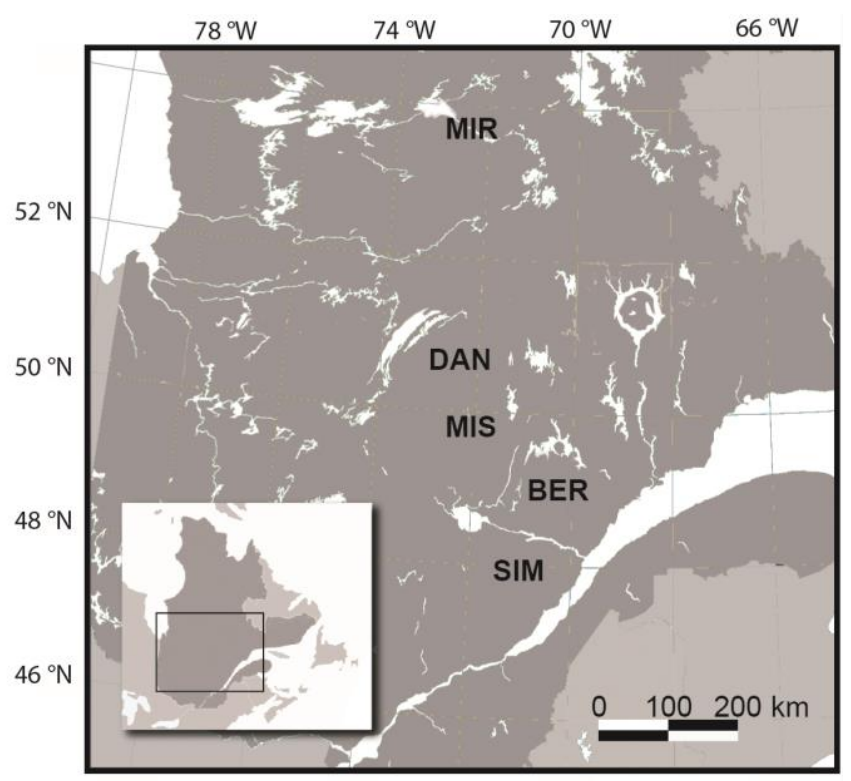


FIGURE 3
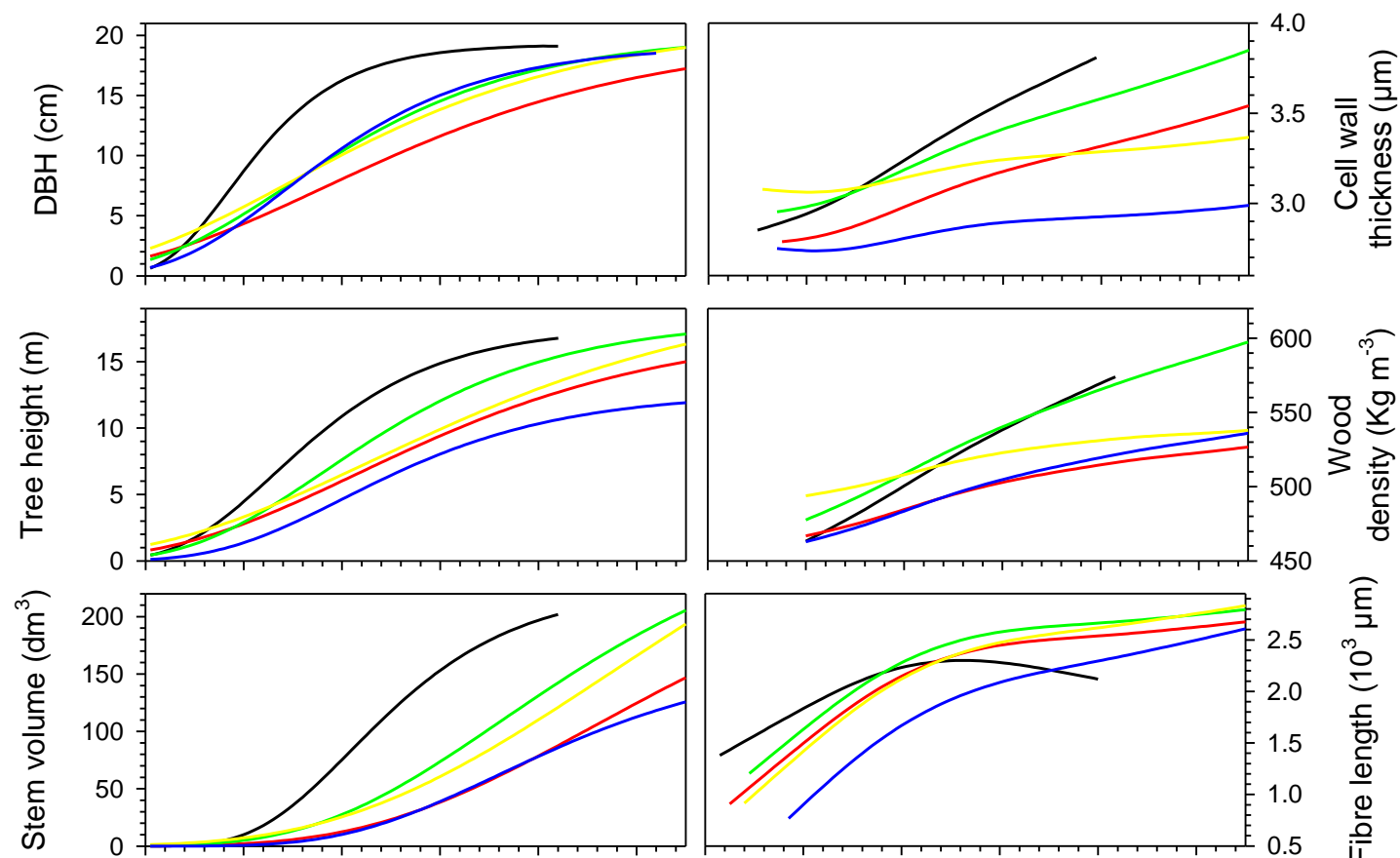

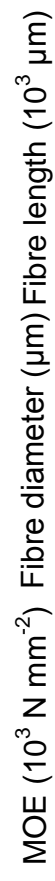
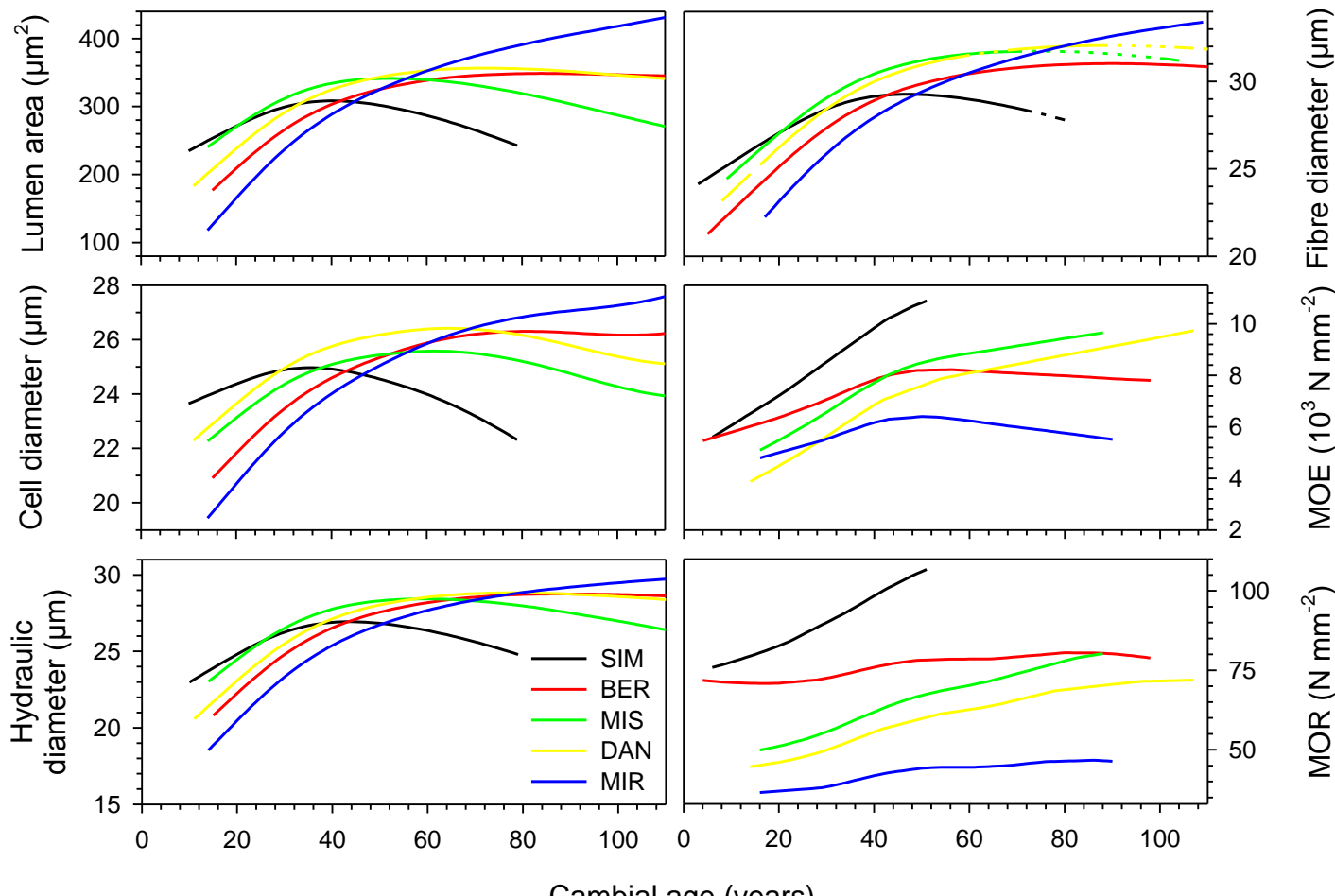

Cambial age (years) 
FIGURE 4

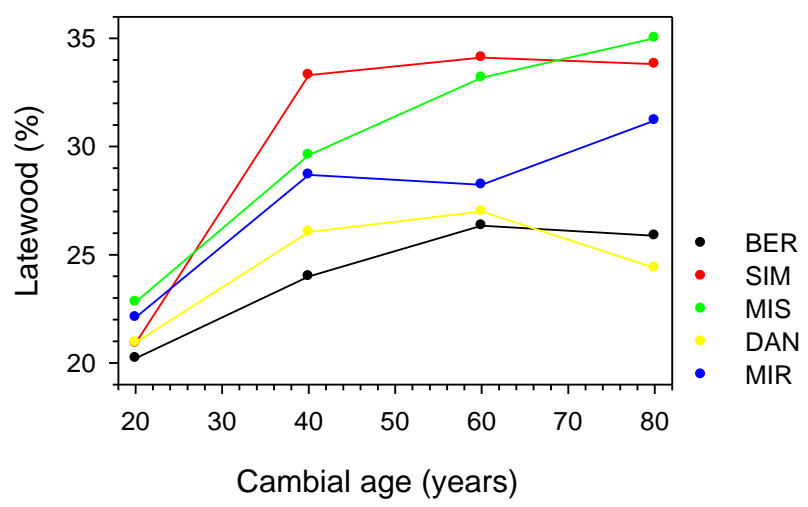




\section{FIGURE QQQ}
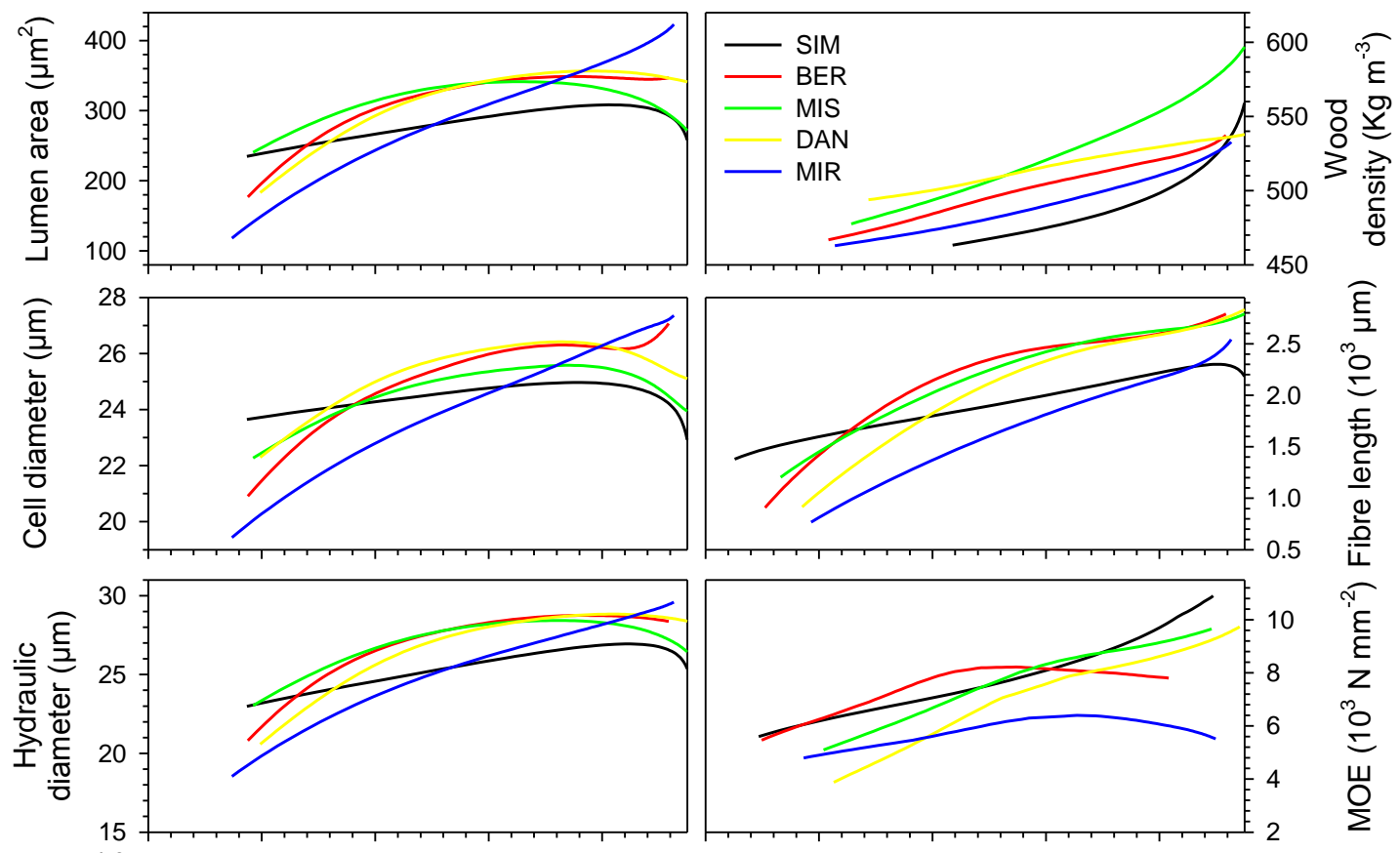

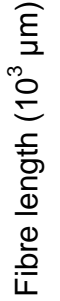

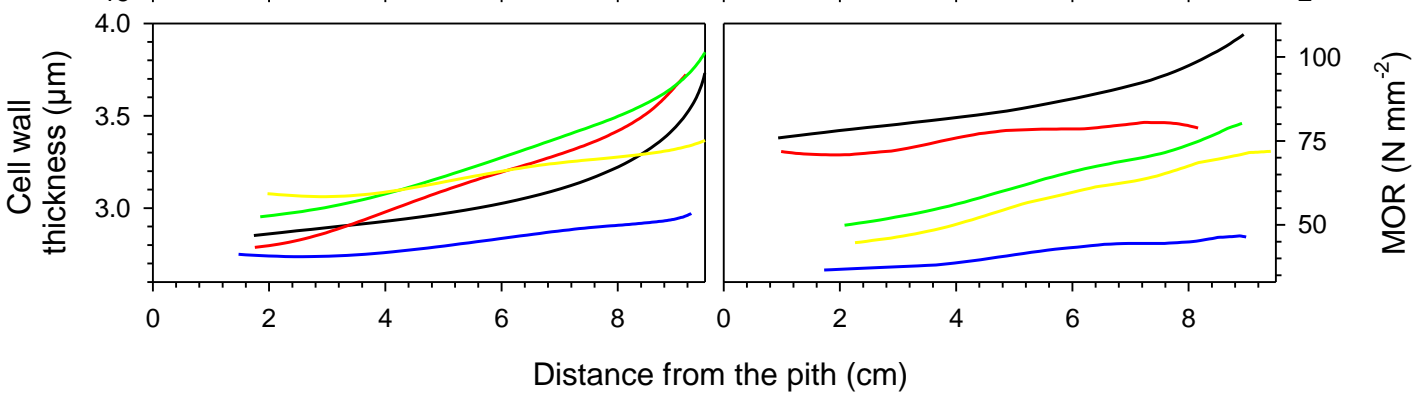


FIGURE 5

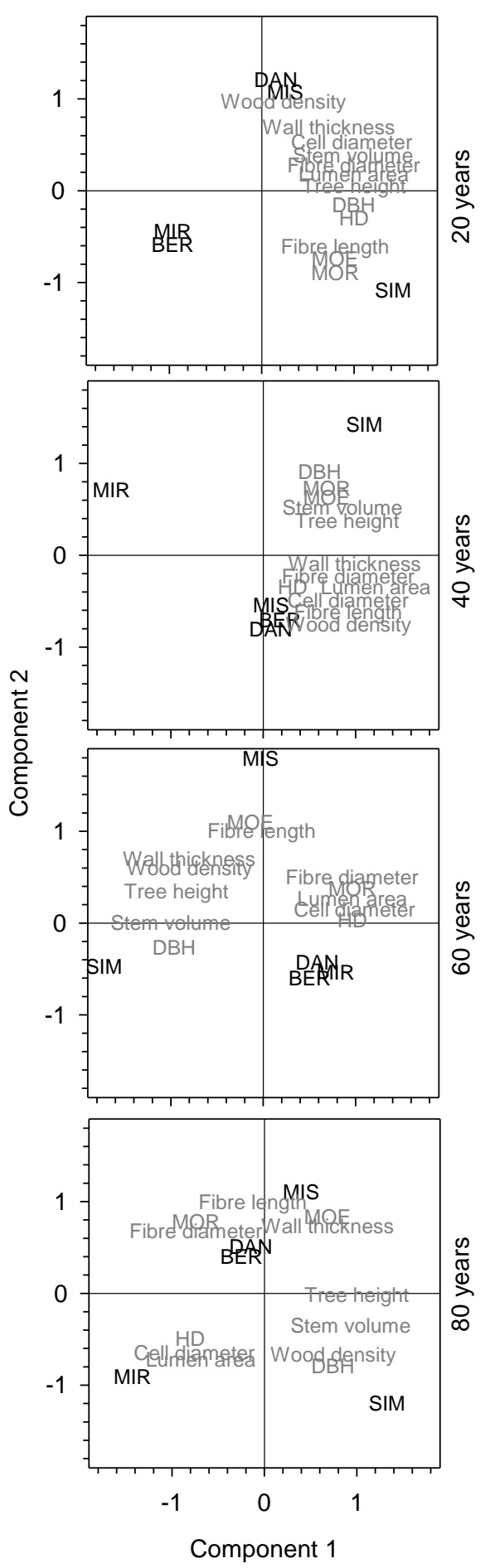



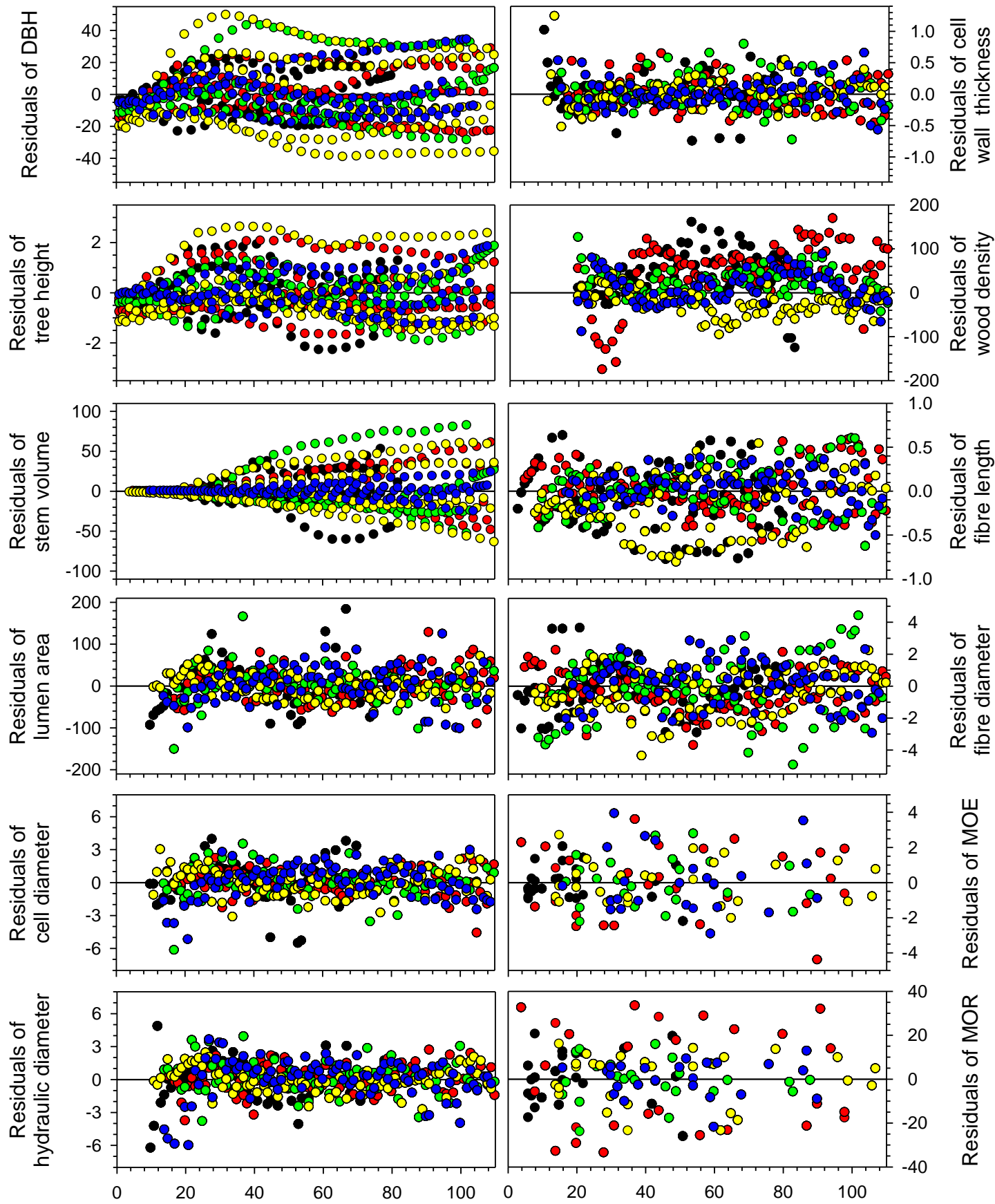

Cambial age (years)

Figure S1 Residuals generated by Gompertz functions and GAMs fitting the variation of the measured traits with cambial age of black spruce trees growing in stands located at different latitudes in the boreal forest of Quebec, Canada. SIM, black; BER, red; MIS, green; DAN, yellow; MIR, blue 